\author{
Matúš KAČÍR ${ }^{1}$, Róbert GREGA ${ }^{2}$ \\ Opiekun naukowy: Róbert GREGA² \\ DOI: https://doi.org/10.53052/9788366249837.10
}

\title{
BUDOWA STANOWISKA TESTOWEGO DO BADANIA WŁASNOŚCI SPRZĘGIEŁ PODATNYCH
}

\begin{abstract}
Streszczenie: Od początku produkcji maszyn z elementami obrotowymi, producenci spotykali się $\mathrm{z}$ takimi problemami jak wyważenie, oscylacje oraz drgania. Te ostatnio wspomniane czynniki często powodowały uszkodzenia elementów oraz całych urządzeń. Celem projektantów stało się eliminowanie niekorzystnych zjawisk/efektów, które objawiają się w postaci uszkodzeń/awarii sprzętu. Najlepszą alternatywą jest używanie sprzęgieł podatnych, dlatego potrzebne są stanowiska badawcze do ich testowania.
\end{abstract}

Słowa kluczowe: podatne sprzężenie wałów, absorpcja/tłumienie nierównomierności momentu obrotowego, koło zamachowe dwumasowe

\section{DEVELOPMENT OF TEST EQUIPMENT FOR THE PROPERTIES MEASUREMENT OF A FLEXIBLE COUPLING}

Summary: Since the beginning of the production of rotational machines, designers have encountered difficulties such as balancing, oscillation and vibration, which have often been destructive to the manufactured equipment. The designer's aim was to eliminate the side effects that manifested themselves in the form of equipment failures. The best alternative was to use a flexible shaft coupling.

Keywords: flexible shaft couplings, torque shock absorption, dual mass flywheel

\section{Introduction}

Different types of flexible shaft couplings have different characteristics. These properties change as conditions change, such as a change in load, a change in speed,

\footnotetext{
${ }^{1}$ Technická univerzita v Košiciach, Strojnícka fakulta, Katedra konštrukčného a dopravného inžinierstva, matus.kacir@tuke.sk

${ }^{2}$ prof. Ing. Róbert Grega, PhD.Technická univerzita v Košiciach, Strojnícka fakulta, Katedra konštrukčného a dopravného inžinierstva, robert.grega@tuke.sk
} 
or a change in torque. The parameters of the same type of flexible coupling also differ depending on the manufacturer and the type of components used in the flexible coupling. We can also consider a dual-mass flywheel used in automobile drives as a flexible coupling [1].

In the load tests of flexible couplings, the values of torsional stiffness, the value of vibration isolation and the elimination of torsional vibration are determined. These parameters are compared and changed by changing the elements of the flexible couplings [2]. In order to achieve reliability of data from individual types of flexible couplings, it is necessary to simulate conditions that are similar to the conditions in specific devices. Subsequently, the flexible couplings can be applied to the machines.

\section{Properties of flexible shaft couplings}

Flexible couplings are essentially disc couplings. The drive disc is connected to the driven disc by flexible elements, which can be made of non-metallic materials (rubber, plastic) or metal (spring steel). They are designed to transmit torque between two shafts and consist of three main parts - the drive disc, the driven disc and the spring member.

Flexible couplings have the following properties:

- torque shock absorption

- changes the critical speed of the gear mechanism

- $\quad$ protects the mechanism from resonant torsional vibrations, caused by torque unevenness

- $\quad$ axiality of connected shafts is not required, mutual axial displacements and angular deflections are compensated

The connection of the two shafts is exposed to random or regular changes in torque. These properties also depending on the design, cause the coupling to be subjected to tensile, compressive, shear or twisting stresses. Both metallic and non-metallic springs can have different geometric shapes and arrangements in the coupling. Depending on the type of material, the shape and the arrangement of the spring, many types of flexible coupling (Fig.1 [4]) can be made [3]. The term flexible coupling can also be understood as a dual-mass flywheel, which will be mentioned in this article.

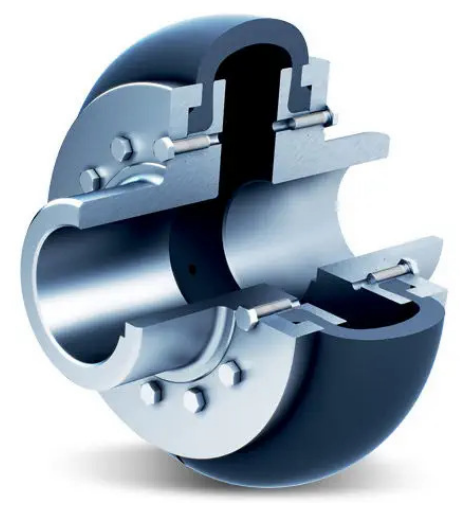

Figure 1. Flexible coupling [4] 


\subsection{Dual mass flywheel}

The dual-mass flywheel (Fig.2.) works like an ordinary flywheel, which at the same time dampens vibrations. The difference between these flywheels is in its main component. The flywheel is flexibly connected to the crankshaft. However, the speed of the flywheel itself remains constant, so the output speed to the gearbox is also constant and relatively vibration-free [5].

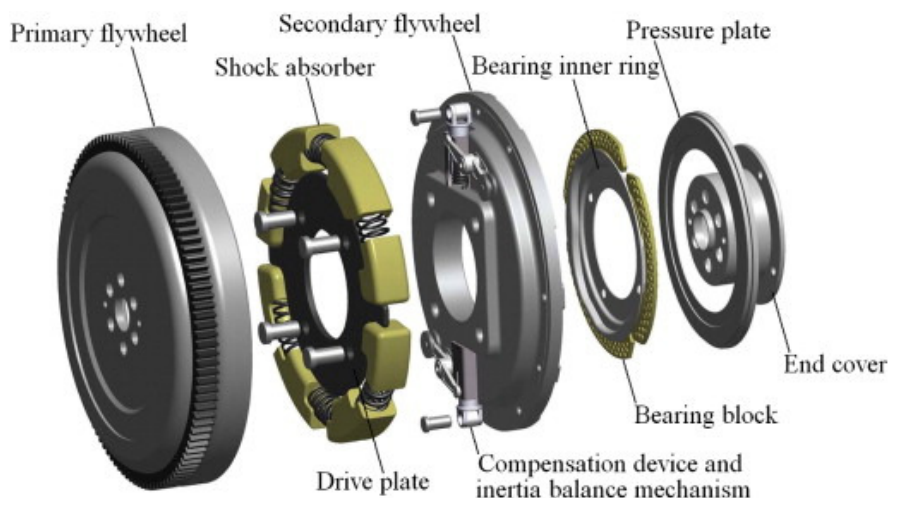

Figure 2. Dual mass flywheel [5]

The best-known manufacturers of dual-mass flywheels are SACHS, VALEO and LUK. The designs of the given manufacturers differ, but each of these manufacturers uses a spring as a damping element [6].

\section{Torsional vibration damping testing device}

Kinematic excitation of torsional oscillations device (Fig. 3) was built by the Technical University in Košice employees to test and identify the properties of flexible couplings with a vision to develop a new type of flexible coupling, or twomass flywheel, where the flexible member will be a gaseous medium [7].

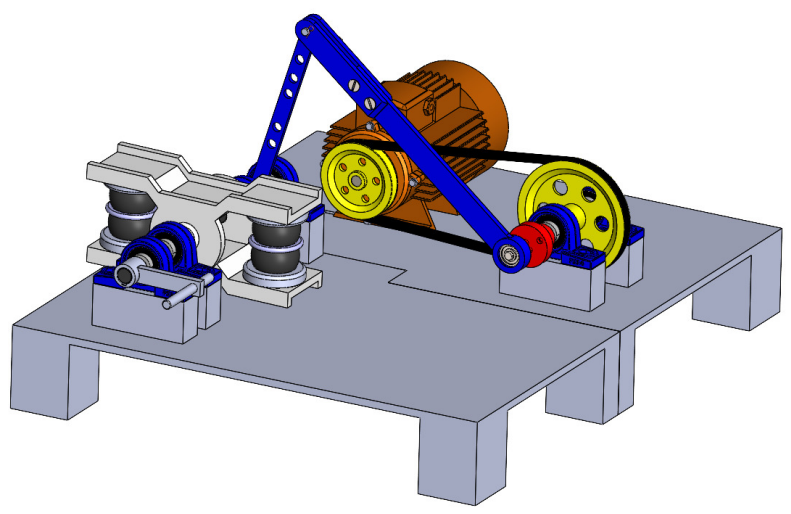

Figure 3. Torsional vibration damping testing device 
The test equipment allows the simulation of different operating modes, which are characterized by different load frequencies, amplitudes and preload voltages. The main part of the test equipment, which allows to simulate the operating conditions, is a transducer that changes the rotational movement to oscillating - in this case (Fig.4.), it is a four-joint mechanism [7].

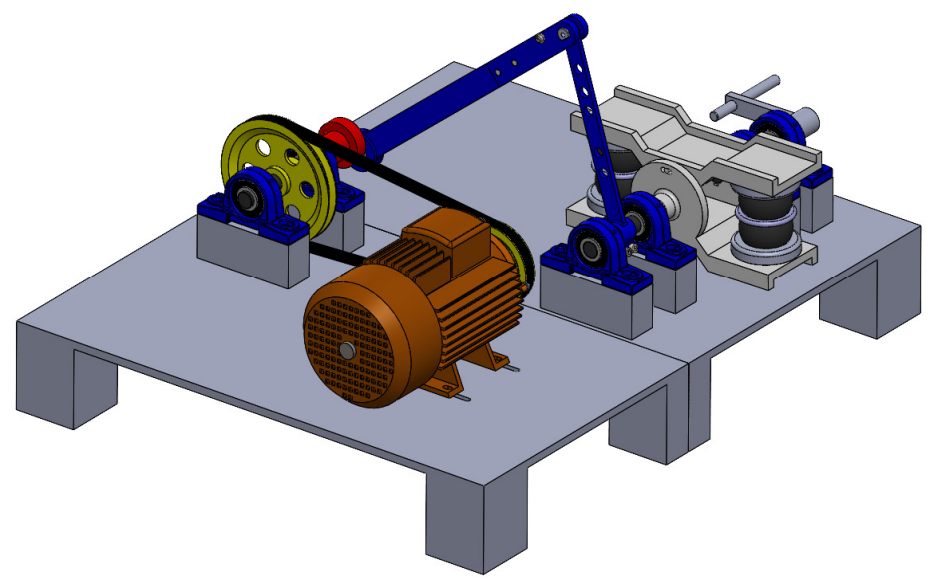

Figure 4. Torsional vibration damping testing device

The device is designed for measurement with a free load on the output. In this method, it is necessary to measure the dependence of the excitation frequency $\omega$ and the excitation amplitude of the coupling rotation $\varphi_{\mathrm{A}} . \varphi_{\max }$ is determined from the measured values. $\varphi_{\max }$ is obtained when the system resonates, which is clear from the theoretical analyses and practical measurements. Since the amplitude of the mass rotation at the input side with the given mass moment $I_{V}$ is determined by the geometry of the four-joint drive mechanism and is therefore known, then the damping coefficient $b$ of the coupling is calculated after determining the moment of inertia at output $I_{Z}$ and oscillation frequency at output $\omega_{2}$ according to formula (1) which is suitable for couplings with linear and nonlinear characteristics [7].

$$
b=\frac{\varphi_{A}}{\varphi_{\max }} \cdot I_{Z} \cdot \omega_{2}
$$

The dynamic torsional stiffness of a linear coupling is calculated according to formula (2)

$$
k_{d y n}=I_{Z} \cdot \omega_{2}^{2}+\frac{1}{4} \cdot b^{2} \cdot \frac{1}{I_{z} * \omega_{2}} .
$$

If we determine the torsional stiffness for a coupling with a nonlinear continuous characteristic, it is necessary to perform at least two measurements for two different deviations of the input amplitude $\varphi_{\mathrm{A}}$. Then, according to the method of equivalent linearization, formula (3) applies [7]. 


$$
\omega^{2}=\frac{k_{e}}{I_{Z}}=\frac{a_{1}+\frac{3}{4} \cdot a_{3} \cdot \varphi_{\max }{ }^{2}}{I_{Z}}
$$

The coefficient characterizing the nonlinearity of the coupling $a_{3}$ is calculated according to formula (4)

$$
a_{3}=\frac{\frac{3}{4} \cdot I_{Z} \cdot\left(\omega_{2}^{I^{2}}-\omega_{2}^{I I}{ }^{2}\right)}{\varphi_{\max }^{I}{ }^{2}-\varphi_{\max }^{I I}{ }^{2}} .
$$

The dynamic torsional stiffness of such a coupling is then calculated according to formula (5).

$$
k_{d y n=} \omega_{2}^{I I}{ }^{2} \cdot I_{Z}-\frac{\omega_{2}^{I^{2}}-\omega_{2}^{I I}{ }^{2}}{\varphi_{\max }^{I}-\varphi_{\max }^{I I}} \cdot \varphi_{\max }^{I I} \cdot I_{Z} \cdot
$$

The measurement method with free mass at the outlet is particularly suitable for accurately determining the dynamic torsional stiffness of flexible couplings [7].

\section{Conclusion}

The constantly improving comfort of passengers in cars leads to the improvement of the components of the entire propulsion system. This also includes the improvement and development of dual-mass flywheels. The device for testing their properties will help us to improve them and design new types of dual-mass flywheels and flexible shaft couplings.

By improving the functions of test equipment, it is possible to obtain more detailed test results and thus increase the quality of test results. By optimizing the dual-mass flywheels, it is possible to achieve more efficient use of the vehicle's power, reduced fuel consumption and increased driving comfort.

\section{Acknowledgments}

This paper was developed within the projects implementation KEGA 029TUKE$4 / 2021$ "Implementation of modern educational approaches in the design of transmission mechanisms, VEGA 1/0528/20 "Solution of new elements for mechanical system tuning".

\section{REFERENCES}

1. TANG X., HU X., YANG W., YU H.: Novel Torsional Vibration Modeling and Assessment of a Power-Split Hybrid Electric Vehicle Equipped With a Dual-Mass Flywheel, 2018.

2. KRAJŇÁK J., HOMIŠIN J., GREGA R., KAŠŠAY P., URBANSKÝ M.: The failures of flexible couplings due to self-heating by torsional vibrations validation on the heat generation in pneumatic flexible tuner of torsional vibrations, 2021. 
3. VELIČKOVÁ E.: Stroje a zařízení - Č́sti strojů, VŠB TU Ostrava, Fakulta bezpečnostního inženýrství, 2010.

4. Stromag Product catalogue, GKN stromag PERIFLEX TT, Catalogue no. D801, 6.2013

5. ZHANG S., ZHOU S.,D.J. \& Niu, E.H.: Design and analysis of a dual mass flywheel with continuously variable stiffness based on compensation principle, 2014.

6. LEE H.J., SHIM J.K.: Multi-objective optimization of a dual mass flywheel with centrifugal pendulum vibration absorbers in a single-shaft parallel hybrid electric vehicle powertrain for torsional vibration reduction.

7. GREGA R.: Monitoring vibrácií mechanických sústav a testovanie pružných spojok, Technická univerzita v Košiciach, Univerzitná knižnica Technickej univerzity v Košiciach, 2019. 